\title{
PENDALAMAN KARAKTER SISWA-SISWI DALAM EKSTRAKURIKULER TEATER DISMA NEGERI 1 ALALAK MENGGUNAKAN OLAH SUKMA
}

\author{
Rofi Shafwan \\ Pascasarjana Institut Seni Indonesia Yogyakarta \\ Institut Seni Indonesia Yogyakarta \\ e-mail : shafwanrofi@yahoo.com
}

Diterima : 12 April 2020. Disetujui : 15 Mei 2020. Dipublikasikan : 10 Juni 2020

(O2020 - DESKOVI Universitas Maarif Hasyim Latif. Ini adalah artikel dengan akses

terbuka di bawah lisensi CC BY 4.0 (https://creativecommons.org/licenses/by/4.0/)

\begin{abstract}
ABSTRAK
Masalah yang ditemukan dalam Ekstrakuikuler Teater di SMA Negeri 1 Alalak adalah siswa kesulitan dalam mempelajari dan memainkan karakter yang mereka perankan. Ibu Ani Nilawardani, M.Pd selaku penanggung jawab Ekstrakurikuler Teater di SMA Negeri 1 Alalak tidak pernah memberikan arahan untuk pendalaman karakter dalam berteater, beliau pernah tepikir untuk mengajak siswa/siswi ekstrakurikuler Teater olah sukma namun ibu Ani tidak jadi melakukannya karena beliau dan pihak sekolah masih ragu-ragu untuk melakukan olah sukma dengan pemahaman bahwa olah sukma bisa membuat siswa/siswi Ekstrakurikuler Tetaer kesurupan. Penelitian ini bertujuan untuk 1.) Mengetahui proses pelaksanaan pendalaman karakter siswa / siswi ekstrakurikuler Teater di SMA NEGERI 1 Alalak melalui olah sukma, menggunakan metode pendekatan kualitatif. Penelitian ini memberikan pengalaman baru terhadap siswa/siswi untuk bisa belajar bersama dan merasakan bagaimana caranya memainkan karakter, karena karakter sangat penting bagi seorang aktor dalam ber teater untuk menciptakan suasana agar para aktor bisa membawakan perannya senyaman dan bisa sebagus mungkin. Sampel penelitian ini adalah Siswa/siswi yang mengikuti ektrakurikuler teater di SMA Negeri 1 Alalak.
\end{abstract}

Kata kunci: Karakter, keaktoran, teater

\section{ABSTRACT}

The problem found in Theater Extracurricular at Alalak 1 Senior High School is that students have difficulty in learning and playing the characters they play. Mrs. Ani Nilawardani, M.Pd as the person responsible for Theater Extracurricular activities at Alalak 1 Senior High School has never given any direction for character deepening in theater, she had thought to invite extracurricular Theater students, though Ibu Ani did not do it because she and the school still hesitant to do sukma with the understanding that if sukma can make students Extracurricular Theater possessed. This study aims to Determine the process of implementing the deepening of the character of students of extracurricular Theater at Alalak 1 Senior High School through processing the sukma, using a qualitative approach method. This research provides new experiences for students to be able to learn together and feel how to play the character. because the character is very important for an actor in performing theater to create an atmosphere so that the acto performs the role as comfortable and can be as good as possible.

Keyword : Character, acting, theater

\section{PENDAHULUAN}

Pembelajaran adalah upaya secara sistematis yang dilakukan guru untuk mewujudkan proses pembelajaran berjalan secara efektif dan efesien yang dimulai dari perencanaan, pelaksanaan dan evaluasi. Kemampuan mengelola pembelajaran merupakan syarat mutlak bagi guru agar terwujud kompetensi profesionalnya. Konsekuensinya, guru harus memiliki pemahaman yang utuh dan tepat terhadap konsep belajar dan mengajar (Aqib, 2014: 66).

Masalah yang ditemukan dalam Ekstrakuikuler Teater di SMA Negeri 1 Alalak adalah siswa kesulitan dalam mempelajari dan memainkan karakter yang siswa perankan. Ibu Ani Nilawardani, M.Pd selaku penanggung jawab Ekstrakurikuler Teater di SMA Negeri 1 Alalak tidak pernah memberikan arahan untuk pendalaman karakter dalam berteater, beliau pernah tepikir untuk mengajak siswa/siswi ekstrakurikuler Teater olah sukma namun ibu Ani tidak jadi melakukannya karena beliau dan pihak sekolah masih ragu-ragu untuk melakukan olah sukma dengan pemahaman bahwa olah sukma bisa membuat siswa/siswi Ekstrakurikuler Tetaer kesurupan.

Peneliti tertantang memberikan Siswa/siswi Ekstrakurikuler Teater di SMA Negeri 1 Alalak untuk melakukan Olah Sukma agar siswa/siswi Ekstrakurikuler Teater bisa merasakan proses olah 
sukma, pihak sekolah juga tidak selalu beranggapan salah kafrah dalam hal pendalaman Karakter melalui Olah Sukma.

Pada proses pembelajaran pendalaman karakter siswa/siswi dalam ekstrakurikuler teater di SMA Negeri 1 Alalak terdapat masalah yang diteliti yatu proses pembelajaran pendalaman karakter siswa/siswi SMA Negeri 1 Alalak melalui olah sukma.

Berdasarkan rumusan masalah di atas, maka tujuan peneliti yang ingin dicapai dalam penelitian ini adalah mengetahui proses pendalaman karakter melalui pembelajaran pendalaman karakter siswa/siswi ekstrakurikuler teater di SMA Negeri 1 Alalak menggunakan olah sukma.

\section{Ekstrakurikuler}

Pengertian ekstrakurikuler menurut Alwi (2002:291), yaitu suatu kegiatan yang berada diluar program yang tertulis di dalam kurikulum seperti latihan kepemimpinan dan pembinaan siswa Kegiatan ekstrakurikuler dilakukan diluar jam mata pelajaran wajib, jadi siswa diberi kebebasan untuk memilih kegiatan ekstrakurikuler yang diminatinya.

\section{Teater}

Menurut Soediro Satoto (2012:4-5) Kata teater berasal dari bahasa Yunani, 'theatron' yang diturunkan dari kata 'theaomai' yang berrti takjub melihat, memandang.

\section{Karakter}

Menurut Zubaedi (2011: 8) Karakter berarti tabiat atau kepribadian seseorang. Mendefinisikan karakter sebagai suatu penilaian subjektif terhadap kepribadian seseorang yang berkaitan dengan atribut kepribadian yang dapat atau tidak dapat diterima masyarakat.

\section{Olah Sukma}

Belajar pemeranan, seni peran, akting tidak dapat lepas dari beberapa unsur atau elemen di dalamnya. Unsur - unsur dalam pemeranan dapat siswa ketahui melalui pembelajaran teori dan praktik dengan materi berupa teknik pemeranan Olah Sukma dan mengenai ruang dengan beberapa unsur pendalam dengan bimbingan guru.

\section{METODE PENELITIAN}

\section{Desain dan Jenis Penelitian}

Metode yang digunakan pada penelitian ini adalah metode kualitatif. Pada penelitian kualitatif, bentuk data berupa kalimat atau narasi dari subjek/responden penelitian yang diperoleh melalui suatu teknik pengumpulan data yang kemudian data tersebut akan di analisis dan diolah dengan menggunakan teknik analisis data kualitatif dan akan menghasilkan suatu temuan atau hasil penelitian yang akan menjawab pertanyaan penelitian yang diajukan. Data yang dianalisis akan berbentuk deskriptif (gambaran) tentang "pendalaman karakter siswa / siswi dalam ekstrakurikuler teater di SMA Negeri 1 Alalak ( Haris Herdiansyah, $2013: 14$ ).

\section{Lokasi dan Objek Penelitian}

Lokasi penelitian ini dilakukan di SMA NEGERI 1 ALALAK yang beralamatkan di Jl. Trans Kalimantan, Hasan Basri, Barito Kuala. Objek Penelitian ini adalah Pendalaman karakter Siswa/siswi dalam ekstrakurikuler teater di SMA Neger 1 Alalak.

\section{Teknik Pengumpulan Data}

Data mutlak diperlukan dalam rana penelitian. Dalam konteks penelitian, data diibaratkan sebagai bahan bakar yang diperlukan kendaraan untuk dapat bergerak.

\section{Studi Lapangan (Observasi)}

Menurut (Matthews and Ross dalam Haris Herdiansyah, 2013 : 129 - 130) mrupakan metode pengumpulan data melaului indra manusia. Berdasarkan pernyataan ini, indra menjadi alat utama dalam melakukan observasi. Tentu saja indra yang terlibat bukan hanya indra penglihatan saja, tetapi indra lainnya pun dapat dilibatkan seperti indra pendengaran, indra penciuman, indra perasa, dan lain sebagainya.

Dalam observasi SMA Negeri 1 Alalak dilakukan selama proses kegiatan ekstrakurikuler Teater berlangsung sampai dengan kegiatan tersebut selesai. Dimana kegiatan observasi dalam penelitian ini adalah untuk mengetahui serta mengamati hal-hal yang berkaitan dengan indikator yang ada pada objek penelitian pada kegiatan Pendalaman Karakter Siswa/siswi dalam ekstrakurkuler teater di SMA Negeri 1 Alalak. Adapun yang diamati adalah proses siswa/siswi dalam melakukan pendalaman karakter dalam ekstrakurikuler teater menggunakan olah sukma.

\section{Wawancara (Interview)}

Wawancara dapat berarti banyak hal atau wawancara memiliki banyak definisi tergantung konteksnya. Menurut (Moleong 2005 dalam Haris Herdiansyah, 2013:29) wawancara adalah percakapan dengan maksud tertentu.

Dalam wawancara tidak terstruktur, peneliti belum mengetahui secara pasti data apa yang akan diperoleh, sehingga peneliti lebih banyak mendengarkan apa yang diceritakan oleh narasumber. Untuk memudahkan proses wawancara peneliti menggunakan alat bantu seperti catatan, alat tulis dan kamera. Wawancara dilakukan kepada Ketua Ekstrakulikuler teater di SMA 1 Alalak Ibu Ani Nilawardani, M.Pd sekaligus sebagai pelatih teater di SMA Negeri 1 Alalak. Dalam wawancara tidak terstruktur peneliti menanyakan bagaimana tentang pelatihan di SMA Negeri 1 Alalak, bagaimana proses siswa untuk bisa memainkan karakter. Dalam obrolan peneliti bersama ibu Ani Nilawardani peneliti menyimak hasil dari tanya jawab atau wawancara tidak terstruktur tersebut. 


\section{Dokumentasi}

Menurut Sugiyono (2013:240) dokumen merupakan catatan peristiwa yang sudah berlalu. Dokumen bisa berbentuk tulisan, gambar, atau karyakarya monumental dari seorang. Dokumen yang berbentuk tulisan misalnya catatan harian, sejarah kehidupan (life histories), ceritera, biografi, peraturan, kebijakan.

Dokumentasi dalam penelitian ini yaitu berupa gambar atau foto yang berkaitan dengan kegiatan Pendalaman Karakter Siswa/siswi dalam Ekstrakurikuler Teater di SMA Negeri 1 Alalak yang kegunaanya untuk melengkapi data kegiatan pembelajaran ekstrakurikuler itu berlangsung.

\section{Analisis Data}

Analisis data adalah proses mencari dan menyusun secara sistematis data yang diperoleh dari hasil wawancara, catatan lapangan, dan bahan-bahan lain, sehingga dapat mudah dipahami, dan temuannya dapat diinformasikan kepada orang lain (Bogdan dalam Sugiyono, 2013:244).

1. Analisa sebelum di lapangan

Analisa ini dilakukan sebelum peneliti terjun ke lapangan dengan membuat proposal penelitian, yang mana proposal tersebut terfokus pada kegiatan ekstrakurikuler teater. Analisa siswa/siswi ekstrakurikuler teater SMA Negeri 1 Alalak brdasarkan hasil wawnacara dengan Ibu Ani Nilawardani tntang karakter, peneliti menganalisa tentang ekspresi wajah siswa.

2. Analisa selama di lapangan

Analisa data dalam penelitian ini dilakukan pada saat pengumpulan data berlangsung dan setelah selesai pengumpulan data yang dilakukan dalam satu bulan penelitian yang dilakukan oleh peneliti. Dimana analisa ini berhubungan dengan teknik observasi dan wawancara serta dokumentasinya sebagai pelengkap dari teknik pengumpulan data tersebut. Analisis ini dilakukan dengan melihat ekspresi wajah siswa dan menghubungkannya dengan pernyataan yang disampaikan oleh siswa mengenai keterangan siswa saat dilpangan.

\section{Keabsahan Data}

Di dalam pengujian keabsahan data, metode penelitian kualitatif menggunakan validityas interbal (credibility) pada aspek nilai kebenaran, pada penerapannya ditinjau dari validitas eksternal (transferbility) dan realibilitas (dependability) pada aspek konsistensi, serta obyektifitas (confirmability) pada aspek naturalis (Sugiyoni, 2014). Pada penelitian kualitatif tingkat keabsahan lebih ditekankan pada data yang diperoleh. Melihat hal tersebut maka kepercayaan data hasil penelitian dapat dikatakan memiliki pengaruh signifikan terhadap keberhasilan sebuah penelitian. Berikut ini terdapat model interaktif dalam analisa data:
a. Data Reduction (Reduksi data)

Reduksi data adalah proses pengorganisasian data dengan cara analisis yang menajamkan, mengarahkan, menggolongkan, dan membuang data yang tidak perlu sehingga membuat suatu kesimpulan. Dalam mereduksi data peneliti menganalisis catatan di lapangan yang berupa hasil observasi serta wawancara dengan memilih kategori data. Proses pendalaman karakter siswa/siswi Ekstrakurikuler melalui olah sukma.Peneliti meminta siswa untuk memberikan pernyataan oleh siswa terkait ekspresi wajah, gerak tubuh mereka saat dilapangan dan menganalisis, menyesuaikan antara pernyataan siswa dan kejadian saat di lapangan, hal ini dilakukan agar bsa menjadi bahan pemikiran untuk analisis.

\section{b. Data Display (Penyajian data)}

Menurut Sugiyono (2016: 341) penyajian data bisa dilakukan dalam bentuk uraian singkat, bagan, hubungan antar kategori, flowchart dan sejenisnya. Miles and Huberman (1984) juga mengatakan yang paling sering diguanakan dalam mentajikan data dalam penelitian kualitatif adalah dengan teks yang bersifat naratif (Sugiyono (2016: 341). Bentuk penyajian data pada penelitian ini yaitu berupa teks deskripsi. Teks tersebut diambil dari catatan. Dalam hal ini peneliti menuliskan deskripsi dari Pendalaman Karakter siswa/siswi dalam ekstrakurikuler teater di SMA Negeri 1 Alalak dari hasil catatan yang disimpan saat penelitian dan dituangkaan dalam teks dekripsi naratif. c. Conclusion Drawing / Verificakation

Menurut Miles and Hurberman langkah ketiga dalam analisa data kualitatif adalah penarikan kesimpulan atau verifikasi. Kesimpulan yang dikemukakan dari tahap awal dan didukung oleh buktibukti yang valid yang ada pada lapangan maka kesimpulan yang dikemukakan merupakan kesimpulan yang kredibel. Sehingga temuan deskripsi atau gambaran sebuah objek yang sebelumnya remangremang menjadi jelas setelah diteliti.

Kesimpulan yang ditemukan pada penelitian ini berupa hubungan interaktif terdapat pada penyajian data yang dikumpulkan dari hasil observasi dalam 5 kali pertemuan. Dalam penelitian kualitatif ini peneliti mendapatkan data-data yang berhubungan dengan proses pendalaman kakter oleh siswa/siswi dalam ekstrakurikuler Teater di SMA Negeri 1 Alalak

\section{HASIL DAN PEMBAHASAN}

\section{Tahap Perencanaan Pembelajaran Pendalaman karakter Siswa/siswi dalam Ekstrakurikuler Teater di SMA Negeri 1 Alalak.}

Pembelajaran ekstrakurikuler teater diajarkan kepada siswa siswi yang aktif mulai kelas X sampai dengan kelas XI, karena siswa siswi kelas XII sudah fokus ujian dan tidak diperbolehkan ikut ekstrakurikuler. Pada pembelajaran pendalaman karakter ada beberapa tahap pengenalan dulu untuk membuat siswa siswi merasa nyaman dan menanamkan rasa penasaran mereka. 
Siswa yang mengikuti pelajaran ada 8 orang, 2 perempuan dan 5 laki-laki, 6 siswa terdiri dari jurusan IPS 5 orang siswa laki-laki, 1 orang siswa perempuan, sedangkan dari jurusan IPA ada 2orang, 1 siswa lakilaki, 1 siswa perempuan.

Selasa, 02 Mei 2017 pukul 16:00 memulai untuk pembelajaran tahapan awal yaitu konsentrasi, pembelajaran konsentrasi di lakukan di dalam kelas XI IPA, 8 orang siswa/siswi yang mengikuti ekstrakurikuer teater sudah siap duduk rapi dan mendengarkan, terlihat ada 6 orang siswa laki-laki dan 2 orang siswa perempuan mereka duduk di kursi lipat yang sudah disediakan di setiap ruang kelas SMA Negeri 1 Alalak.

Pada pembelajaran Konsentrasi 8 orang siswa/siswi yang mengiuti ekstrakurikuler teater di SMA Negeri 1 Alalak terlihat mendengarkan, siswa pokus memahami apa yang peneliti sampaikan, raut wajah 8 orang siswa/siswi seperti rasa penasaran dan rasa ingin tahu lebih dalam lagi, menganggukan kepala, mata yag terlihat memperhatikan,wajah siswa terbawa pada pembelajaran, tiba saatnya mereka bertanya Anna : Kak bagaimana cara termudah untuk konsentrasi? Peneliti menjawab: giat berlatih, mau mencoba, tidak pantang menyerah, kalau kamu sudah bisa konsentrasi maka akan mudah konsentrasi itu di aplikasikan dimana saja termasuk dalam teater. Saya lajut lagi menyampaikan materi konsentrasi sampai jam terakhir di pukul 18:30 para siswa/siswi ekstrakurikuler teater di persilahkan untuk pulang dan mengingat apa yang sudah disampaikan. Siswa/siswi ekstrakurikuler teater memberikan respon yang bagus pada tahapan awal ini. Pada tahapan penjelasan konsentrasi oleh peneliti kepada Siswa/Siswi SMA Negeri 1 Alalak terlihat bingung, mereka masih sangat awam mendengar penjelasan konsentrasi yang peneliti jelaskan, hal ini bisa dilihat dari cara pandang mereka menyimak penyampaian peneliti, cara mereka mendengarkan apa yang peneliti sampaikan dengan sangat membigungkan, wajah yang masih sangat awam dengan materi-materi yang disampaikan oleh peneliti, dari sini saya mulai merubah cara penyampaian dengan pendekatan lebih perlahan, lebih memberikan ruang kepada siswa/siswi untuk bertanya dan memberikan mereka keleluarsaan untuk menyimak lebih kuat. Peneliti akan melanjutkan materi setelah mereka memberikan jawaban yang sesuai dengan apa yang peneliti jelaskan dan ternyata mereka mulai memahami,walaupun perlahan, diulang diulang sampai mereka mampu memahami, bagi saya tidak masalah sedikit banyaknya waktu yang saya gunakan untuk materi ini yang penting siswa/siswi ekstrakurikuler teater disini memahami dengan baik tentang dasar dasar pemahaman pendalaman karakter agar mereka bisa bersaing diluar sana menghadapi banyak warna.

Imajinasi merupakan daya khayal, gambaran sesuatu atau kemampuan membayangkan sesuatu dalam pikiran. Proses kreatif seorang seniman biasanya diawali dari sebuah imajinasi. Dengan imajinasinya, seniman akan menciptakan kreasi seni. Dengan imajinasi pula ia bisa leluarsa mengembara dalam dunia khayal yang sulit diraih dikehidupan nyata. Kemampuan imajinasi seseorang akan cepat berkembang jika sering digunakan dan dilatih.

Imajinasi memiliki peranan penting untuk lebih memperdalam persfektif. Seni adalah hasil imajinasi, demikian juga halnya dengan karya seorang pengarang drama. Tujuan seorang aktor adalah mempergunakan tekniknya untuk merubah lakon itu menjadi aktualitas teater. Dalam proses ini imajinasi memainkan peranan yang sangat penting sekali. Imajinasi adalah suatu cara bagi seorang aktor untuk mendekati pikiran dan perasaan karakter/tokoh yang akan dimainkan sehingga dia dapat menempatkan dirinya dalam situasi si tokoh. Metode ini merupakan proses imajinasi dimana di aktor melakukan identifikasi dengan karakter/tokohnya. Disetiap identifikasi dengan tokohnya, si aktor harus melihat pengalaman hidupnya dan pengalaman hidup yang paling relevan untuk ditransfer ke pengalaman hidup yang dimiliki si tokoh. Si aktor harus mampu menyelidiki asal mula dirinya sendiri untuk dapat tulus dan jujur pada realita eksistensi dirinya yang baru. Imajinasi menciptakan hal-hal yang mungkin ada atau mungkin terjadi, sedangkan fantasi membuat hal-hal yang tidak ada, dan tidak pernah ada. Tapi siapa tahu, suatu hari kesemuanya itu mungkin ada. Bagi seorang aktor, proses kreatif ini dipimpin oleh imajinasinya Stanislavsky (1980 : 137).

Jumat, 05 Mei 2017 pukul 16:00 memulai untuk pembelajaran Imajinasi. Pembelajaran Imajinasi di lakukan di dalam kelas XI IPA, 8 orang siswa/siswi yang mengikuti ekstrakurikuer teater sudah siap duduk rapi dan mendengarkan, terlihat ada 6 orang siswa lakilaki dan 2 orang siswa perempuan mereka duduk di kursi lipat yang sudah disediakan di setiap ruang kelas SMA Negeri 1 Alalak. Pada pembelajaran imajinasi siswa/siswi ekstrakurikuler teater SMA Negeri 1 Alalak baik mendengarkan materi yang disampaikan oleh peneliti 8 orang siswa/siswi pokus mendengarkan ,menyimak apa yang disampaikan mengenai apa itu Imajinasi. Salah satu siswi namanya Anna selalu mengangguk anggukan kepalanya dari apa yang dia simak, Abrar terlihat berandai-andai seolah-olah dia sedang praktik langsung mengenai imajinasi, sementara siswa/siswi lain tidak terlalu terlihat perbedaannya dibandingkan 2 siswa/siswi Anna dan Abrar. Pada pembelajaran dan pertemuan yang kedua ini para siswa/siswi mendengarkan dengan baik hasil pembelajaran, terbukti saat ditanya oleh peneliti mereka antusias untuk memberikan tanggapan masingmasing.

Pada tahapan pembelajaran Imajinasi pada siswa/siswi SMA Negeri 1 Alalak, peneliti menyampaikan dan menjelaskan secara perlahan bagaimana imajinasi itu dan seperti apa imajinasi itu terjadi, bergerak dari pembelajaran konsentrasi dan kali ini belajar tentang imajinasi siswa/siswi ekstrakurikuler teater SMA Negeri 1 Alalak sudah mulai memahami, 
walaupun kendalanya peneliti harus berbicara dan menjelaskan perlahan mengingat dasar mereka belum pernah belajar hal seperti ini.

Siswa semua terlihat riang tersenyum dan mulai menunjukan apresiasinya terhadap pembelajaran ini, peneliti memaklumi karena ini masih awalan dan mereka masih belum paham apa yang akan terjadi setelah ini, tapi seiring pemelajaran penjelasan yang peneliti sampaikan terlihat mereka mulai antusias.

Pada dasarnya teknik observasi digunakan untuk melihat dan mengamati perubahan fenomenafenomena social yang tumbuh dan berkembang yang kemudian dapat dilakukan perubahan atas penilaian tersebut, bagi pelaksana observaser untuk melihat obyek moment tertentu, sehingga mampu memisahkan antara yang diperlukan dengan yang tidak diperlukan (Margono, 2007:159).

Apabila seorang aktor akan memerankan watak dan tokoh tertentu maka ia dapat melakukan observasi yang difokuskan pada tokoh yang mirip atau sama. Apabila memungkinkan, lakukan observasi dengan waktu yang cukup sehingga gerak-gerik tokoh tersebut dapat lebih mendetail untuk diamati. Dan hasil observasi tersebut, kemudian dihidupkan melalui ingatan emosi dan daya imajinasi sehingga dapat ditampilkan secara total. Peneliti memberikan cara untuk membiasakan mengamati orang-orang disekitar lingkungan berdasarkan kriteria berikut

1. Profesi : Guru, dokter, tentara, mahasiswa, nelayan dan sebaginya.

2. Umur : Muda, remaja, dewasa, dan tua.

3. Watak : sombong, penyayang, ramah, pendiam dan sebagainya

Selasa, 09 Mei 2017 pukul 16:00 ruang kelas XI IPA kembali disambung pembelajaran megenai pendalaman karakter siswa/siswi dalam ekstrakurikuler teater di SMA Negeri 1 Alalak, pada pertemuan ke tiga ini peneliti akan menyampaikan materi tentang observasi yang sebelumnya sudah dibahas mengenai imajinasi di hari Jumat tanggal 09 Mei 2017. Delapan (8) Orang siswa/siswi yang mengikuti ekstrakurikuler teater kembali hadir, mereka duduk di kursi lipat yang sudah disediakan, mereka mendengarkan penyampaian pembelajaran tetang apa itu observasi. Siswa/siswi terlihat berandai- andai mereka memaknai pembelajaran ini terbukti saat ditanya mereka antusias menjawabnya dan mereka menjawab dengan jawaban yang hampir sama yang dapat saya simpulkan. Mereka saling berbicara satu sama lain disela sela saya memberikan waktu untuk bercanda sedikit.

Kegiatan pembangkitan emosi dan perasaan yang dimaksudkan adalah suatu kegiatan untuk mengontrol emosi perasaan dan hati dengan cara memejamkan mata secara perlahan masuk dalam kondisi tak sadar atau fokus dalam trans masing-masing dengan mendengarkan instruktur dalam mengarahkan fikiran peserta untuk lebih relaks dan mendapatkan ketenangan diri (Elias Jack 2009 : 82). Ernawati, E. (2019) juga mengatakan dalam tulisannya yang berjudul Kosmologi sebagai Pijakan Kreasi dalam
Berkarya Seni (Cosmology as the Foundation of Creation in Artwork), menyatakan bahwa melalui rasa, akan terbuka lebar bagi seniman untuk diselami, karena rasa juga berarti éling (ingat) akan asal-usul diri sendiri, sehingga mengetahui atau mengenal apa yang akan dilakukan dalam berkarya selanjutnya.

Jumat, 12 Mei 2017 pukul 16:00 bertempat di ruang kelas XI IPA SMA Negeri 1 Alalak kembali peneliti masuk kelas untuk pembelajaran selanjutnya yaitu Emosi, perasaan dan Pikiran dimulai pembelajaran pembahasan emosi dan perasaan, siswa/siswi Ekstrakurikuler teater SMA Negeri 1 Alalak berjumlah 8 orang duduk dikursi lipat mereka kembali mendengarkan materi-materi yang disampaikan oleh peneliti yang pada hari ini menyampaikan 2 buah materi sekaligus. Rasa penasaran siswa tentang pendalaman karakter mulai meninggi, materi demi materi perlahan disampaikan sampai pertemua ke empat hari ini, terlihat siswa/siswi lebih aktif dari pada pertemuan pembelajaran sebelumnya pada hari ini pertemuan ke empat siswa/siswi ekstrakurikuler teater SMA Negeri 1 Alalak lebih aktif bertanya, membahas, berkomentar, tak selang penjelasan mereka sudah antusias menanyakan, ada juga yang menyamaikan pendapatnya dengan bahasa dia sendiri tentang pengertian apa itu emosi dan perasaan. Abrar menyampaikan pendapatnya. Abrar adalah salah satu murid disana yang juga antusias bertanya, berkomentar dan berpendapat.

Penjelasan mengenai emosi dan perasaan ini merupakan penjelasan yang menarik menurut Abrar salah satu murid di SMA Negeri 1 Alalak. Penyampaian materi meningkat dari segi kecepatan karena siswa sudah semakin mendengarkan, hal ini terlihat semua siswa yang mengikuti bisa apresiasi dengan pembelajaran, tertawa dan memberikan tanggapan kepada siswa/siswi lain yang berbicara.

Berpikir, ini terdapat beberapa pendapat, diantaranya ada yang menganggap sebagai suatu proses asosiasi saja pandangan semacam ini dikemukakan oleh kaum Asosiasionist. Sedangkan Kaum Fungsionalist memandang berpikir sebagai suatu proses penguatan hubungan antara stimulus dan respons. Diantaranya ada yang mengemukakan bahwa berpikir merupakan suatu kegiatan psikis untuk mencari hubungan antara dua objek atau lebih. Secara sederhana, berpikir adalah memproses informasi secara mental atau secara kognitif. Secara lebih formal, berpikir adalah penyusunan ulang atau manipulasi kognitif baik informasi dari lingkungan maupun simbol-simbol yang disimpan dalam long term memory. Jadi, berpikir adalah sebuah representasi simbol dari beberapa peristiwa atau item Seorang aktor harus mampu menghayati setiap situasi yang diperankan. Apabila aktor harus memerankan adegan menangis, maka ia harus betul-betul terlihat menangis, begitu juga saat memerankan adegan tertawa, terkejut, marah dan sebagainya. Aktor harus mampu secara sempurna menyelami jiwa tokoh yang dibawakan serta 
menghidupkan jiwa tokoh itu sebagai jiwanya sendiri, sehingga penonton merasa yakin bahwa yang ada di pentas bukanlah diri sang aktor tetapi diri tokoh yang diperankan (Khodijah, 2006:117).

Penjelasan tentang materi pikiran kepada siswa/siswi SMA Negeri 1 Alalak oleh peneliti dan respon para siswa/siswi tentang materi ini adalah mereka memahami bahwa pikiran merupakan alat bathin untuk berpikir dan mengingat, pikiran mempunyai nilai kuat untuk gagasan yang baik.

Konsentrasi merupakan upaya memusatkan pikiran dan daya kesanggupan untuk mengarahkan / memfokuskan semua kekuatan rohani dan pikiran kearah satu sasaran yang jelas secara terus menerus. Konsentrasi merupakan hal yang cukup sulit dilakukan jika tidak diawali dengan latihan yang serius. Apabila anda sering melatih diri untuk konsentrasi maka anda akan mempunyai kebiasaan yang teguh dalam menghadapi suatu kejadian. Bagi seorang aktor, konsentrasi berguna dalam menyelami watak dan kepribadian tokoh yang sedang diperankannya.Dalam latihan konsentrasi, penelitian menyampaikan beberapa teknik latihan untuk siswa/siswi SMA Negeri 1 Alalak yang bisa dicoba saat dirumah :

1. Siswa diminta membaca sebuah buku atau majalah.

2. Ketika proses membaca, siswa diminta memutar musik dari CD player.

3. Daya konsentrasi akan diuji dengan suara musik tersebut.

4. Apabila suara musik lebih dominan memenuhi pikiran dibandingkan

\section{KESIMPULAN}

Berdasarkan penelitian yang telah dilakukan dapat diambil kesimpulan yaitu dalam penelitian ini peneliti berhasil menyimak dan mengamati proses pendalaman karakter dalam ekstakurikuler teater di SMA Negeri 1 Alalak menggunakan olah sukma.

\section{Saran}

Berdasarkan penelitan yang dilakukan oleh peneliti. Peneliti memberikan saran yang dapat dijadikan masukan agar peneliti selanjutnya bisa lebih baik lagi, khususnya dalam pembelajaran teater untuk hal pendalaman karakter.Ada pun saran dari peneliti yaitu untuk masalah teater diajarkan oleh lulusan seni budaya mesikupun bukan lulusan teater murni

\section{DAFTAR PUSTAKA}

Aqib, Zainal. 2014. Model-model, Media, dan Strategi Pembelajaran Kontekstual (Inovatif). Bandung : Yrama Widya.

Alwi, Hasan. 2002. Kamus Besar Bahasa Indonesia Edisi Ketiga : Jakarta Balai Pustaka

Ernawati, E. (2019). Kosmologi sebagai Pijakan Kreasi dalam Berkarya Seni (Cosmology as the Foundation of Creation in Artwork). INVENSI (Jurnal Penciptaan Dan Pengkajian Seni), 4(2), 113-129.

Herdiansyah, Haris. 2013. Wawancara, observasi dan Focus Groups. Jakarta : PT Raja Grafindo Persada.

Margono. 2007. Metologi Penelitian Pendidikan Komponen MKDK. Jakarta : PT. Rineka

Sugiyono. 2013, Metode Penelitian Pendidikan (Pendekatan Kuantitatif, kualitatif dan R\&D). Bandung : Alfabeta

Sugiyono. (2016). Metode Penelitian Kuantitatif, Kualitatif dan $R \& D$. Bandung: PT Alfabet

Stanislavsky, Constantin.1980. Persiapan Seorang Aktor, Jakarta : Pustaka Jaya Cipta

Satoto, Soediro. 2012. Analisis Drama dan Teater. Yogyakarta : Penerbit Ombak

Zubaedi. 2011. Desain Pendidikan Karakter. Bengkulu : Kencana Prenada Media Group 